\title{
Ortaokul Düzeyinde Dijital Hikaye Anlatımının Yansıtıcı Düşünme Becerisi Üzerindeki Etkisinin İncelenmesine Yönelik Deneysel Bir Çalışma
}

\author{
Mustafa SARITEPECI, Dr, Milli Eğitim Bakanlığı, mustafasaritepeci@gmail.com, http://orcid.org/0000-0002-6984-0652
}

\begin{abstract}
Öz: Bu çalışmada ortaokul düzeyinde dijital öyküleme yönteminin katılımcıların yansıtıcı düşünme becerileri üzerindeki etkilerinin incelenmesi amaçlanmıştır. Bu çerçevede bu çalışmada yarı deneysel desen kapsamında ön-test son-test kontrol gruplu model kullanılmıştır. Çalışma grubu kontrol grubunda 35 ve deney grubunda 33 olmak üzere toplam 68 7. sınıf öğrencisinden oluşmaktadır. Deney grubunda dersler dijital hikayeleme etkinlikleriyle sürdürülürken kontrol grubunda derslerde araştırma-inceleme etkinliklerine yer verilmiştir. Uygulama 11 hafta sürdürülmüş olup her iki grupta da biri bireysel diğeri işbirlikli olmak üzere iki farklı etkinlik yapılmıştır. Uygulama öncesi ve sonrasında gruplardan veri toplamak için yansıtıcı düşünme ölçeği kullanılmıştır. Katılımcılardan toplanan verilerle yapılan çalışmalar doğrultusunda kontrol grubunda iki kişi uç değer oluşturduğu için analiz sürecine dahil edilmemiştir. Çalışmanın bulgularına göre ön-test puanlarına göre düzeltilmiş son-test puanları arasında, deney grubu lehine anlamlı farklılık bulunmuştur. Buna göre dijital hikayeleme etkinliklerinin kullanımının katılımcıların yansıtıcı düşünme becerilerinin gelişimi üzerinde etkili olduğu sonucuna ulaşılmıştır. Ayrıca katılımcıların dersin çevrim-içi öğrenme ortamında gerçekleştirdikleri etkinlik/ödev sayısının yansıtıcı düşünme becerisinin gelişimi üzerinde etkili olduğu tespit edilmiştir.
\end{abstract}

Anahtar Kelimeler: yansıtıcı düşünme, dijital hikaye anlatımı, sosyal bilgiler dersi, hikaye anlatımı

\section{An Experimental Study on the Investigation of the Effect of Digital Storytelling on Reflective Thinking Ability at Middle School Level}

\begin{abstract}
In this study, it was aimed to investigate effect of digital storytelling method on participants' reflective thinking skill at level of middle school. In this framework, pre-test post-test control group model was used under semi-experimental design in this study. Study group consisted of a total of 68 7th grade students, 35 in control group and 33 in experimental group. In the experiment group, the lessons were continued with digital storytelling activities, while in the control group, lessons included research and investigation activities. The application was continued for 11 weeks and two different activities were conducted in both groups, one being the individual and the other cooperating. "Reflective Thinking Scale" was used for data collection prior and after implementation. Two participants in control group didn't included analysis process because they creates outlier. According to findings of the study, it was found a significant difference among groups' corrected post-test scores, favoring the experimental group. Accordingly the use of digital storytelling activities has an impact on the development of participants' reflective thinking skills. In addition, it has been determined that the number of activities/assignment performed by the participants in the online learning environment of the course is effective on the development of reflective thinking ability.
\end{abstract}

Key Words: reflective thinking, digital storytelling, social study course, storytelling 


\section{GíRiş}

Günümüzde bilginin miktarındaki sürekli artış birey ve toplumun gelişimi ve dönüşümünde etkili olmaktadır. Bu gelişim ile birlikte toplumda bireyin rolü bilgiyi olduğu gibi depolamaktan öte, bilgiyi kullanabilme, sorgulayabilme, yeni bilgi üretebilme, transfer edebilme ve karşılaştığı problemlere çözüm üretme olarak değişmiştir (Lai \& Land, 2009). Nitekim bu dönüşümle birlikte eğitim süreçlerinde öğrencilerin bilgi toplama, yönetme, üretme, transfer etme ve yansıtma gibi 21. yüzyılda zorunlu hale gelen becerileri içeren yeterlikleri kazanmalarını sağlamak amaçlanmaktadır (Partnership for 21st Century Skills, 2007). Bu noktada özellikle öğrenenlerin yansıtıcı düşünme becerilerinin önemli bir role sahip olduğu söylenebilir (Strampel \& Oliver, 2007). Bu bağlamda eğitim ortamlarının öğrenenlerin edindikleri bilgilerle ilgili olarak sorgulama, nedenleme ve değerlendirme (Kızılkaya \& Aşkar, 2009) yapabildikleri öğrendiklerini yansıma olanaklarına sahip olması gerekmektedir.

Yansıma, öğrenenin deneyimlerinden bir zihinsel model oluşturma süreci olarak ifade edilebilir. Daha basit bir anlatımla yansıma, öğrenenin yaşadığı deneyimler sonucunda kendi öğrenme sürecini nasıl yapılandırdığını çeşitli yöntemlerle ifade etmesidir (Prensky, 2001). Yansıtıcı öğrenme, içerik birimlerini eleştirel bir bakış ile irdeleyerek daha iyi anlamayı ve bilgi transferini destekleyen güçlü bir öğrenme deneyimi sürecidir (Strampel \& Oliver, 2007). Buna karşın çağımızda öğrenilenleri yansıtma için daha az zaman ve fırsat vardır (Prensky, 2001). Örneğin sosyal bilgiler dersinde, öğrencinin analiz etme, eleştirel düşünme, işbirlikli çalışma, bağımsız hareket edebilme ve araştırma yapma gibi olanaklar sunan yöntemlerin kullanımının tavsiye edilmesine (Alkan, 1998) karşın pratikte sosyal bilgiler dersinde yer alan konularla ilgili kavramların ve bilgilerin genel olarak sözlü olarak öğrencilere aktarıldığı anlaşılmaktadır (Altınışık \& Orhan, 2002). Buna karşın Talim Terbiye Kurulu Başkanlığı [TTKB] (2010) tarafından hazırlanan sosyal bilgiler programında öğretmenin sosyal bilgiler dersi öğretiminde "sosyal bilimler olarak sosyal bilgiler" ve "yansıtıcı düşünme olarak sosyal bilgiler" yaklaşımlarını göz önünde bulundurmaları gerektiği vurgulanmaktadır. Bu çerçevede öğrenme öğretme sürecinde öğrenenlerin gerçek yaşam problemlerini deneyimlemelerine olanak tanınması ve öğrenenlerin problem çözme sürecinde öğrenmelerini yansıtmalarının sağlanması gerektiği üzerinde durulmaktadır (TTKB, 2010). Ancak pratikte ağırlıklı olarak sunum yönteminin tercih edilmesi, genel olarak soyut konuların yer aldığı sosyal bilgiler dersinde (Şeker-Sezginsoy, 2016) öğrencilerin yansıtıcı düşünme deneyimi edinmelerinin önündeki en önemli engellerden biri olduğu söylenebilir. Ayrıca bir diğer önemli engel sınıfların kalabalık olması gibi nedenlerden dolayı öğrenme-öğretme süreçlerinde yansıtıcı düşünme aktivitelerine yeterli zaman ve fırsat sunulamaması olarak gösterilebilir (Strampel \& Oliver, 2007).

Bu bağlamda gelişen teknolojilerle birlikte öğrenme öğretme süreçlerinde öğrenenlere kendi öğrenmelerini yansıtmak için yeni fırsatlar sunulabilir (Smeda, Dakich, \& Sharda, 2014). Ancak, bu yenilikçi teknolojilerin pedagojiyle bütünleştirilmesi öğrenme süreci için gerekli bir unsurdur (Neo \& Neo, 2010). Bu tür teknoloji entegrasyonuna örnek olarak geleneksel hikaye anlatımı yöntemini çoklu-ortam öğeleri ile bütünleştiren dijital hikaye anlatımı [DHA] (Sizemore \& Zhu, 2011) sunulabilir. Ayrıca dijital hikaye etkinliklerinin soyut düşünme becerisinin kazandırılmasında ya da geliştirilmesindeki destekleyici yapısı (Şeker-Sezginsoy, 2016) sosyal bilgiler öğretiminde önemli bir seçenek olmasını sağlayan bir diğer nedendir.

\subsection{Yansıtıcı Düşünme}

Alanının öncülerinden Dewey (1933) yansıtıcı düşünmeyi, herhangi bir inanç ya da sözde bilgi biçiminin, onu destekleyen gerekçeler ve buna bağlı eğilimler ışığında aktif, ısrarlı ve dikkatli bir şekilde düşünmeyi içeren bir süreç olarak ifade etmektedir. Diğer bir deyişle yansıtıcı 
düşünme süreci, başlarda tutarsız ve belirsizliğin olduğu bir duruma tutarlılık ve belirginlik kazandıran düşünme süreci olarak ifade edilmektedir (Dewey, 1933; Schön, 1983).

Yansıtıcı düşünme faaliyetlerinde öğrenenler daha fazla bireysel sorumluluğa sahip olmakta (Karaoglan-Yilmaz \& Keser, 2016; Ünver, 2003) ve öğrenenlerin öğrenme hedeflerini belirlemeleri ile öğrenme eksik ya da yanlışlarını düzeltmelerine olanak tanınmaktadır (Ünver, 2003). Ayrıca yansıtıcı düşünme, öğrenenlerin ders süreçlerinde kasıtlı olarak düşünmelerini sağlayarak ön öğrenmeleri ile yeni edindikleri bilgiler arasında bağlantı kurmalarına olanak tanır (Genç, 2016). Böylelikle de yansıtıcı düşünme etkinliklerini içeren ortamlarda, öğrenenler daha fazla bireysel sorumluluk almakta ve bu durum öğrenenlerin kendi bilişsel gelişim süreciyle ilgili farkındalığını desteklemektedir (Karaoglan-Yilmaz \& Keser, 2016). Jonassen ve Carr (2000) teknoloji destekli aktivitelerin derinlemesine yansıtıcı düşünme oluşturmak amacıyla kullanılabileceğini vurgulamaktadır (Akt. Karaoglan \& Keser, 2016). Burada ifade edilen teknoloji destekli aktivitelerinden biri de dijital hikaye anlatımıdır. DHA ile öğrenenlere farklı etkinlikler çerçevesinde yansıtıcı öğrenme etkinliklerine katılım fırsatları sunulmaktadır. Bu tespiti destekler biçimde Barrett (2006) DHA'nın öğrenci katılımı, derinlemesine öğrenme için öğrendiklerini yansıma, proje temelli öğrenme ve teknoloji entegrasyon stratejilerini birleştirdiği ve kullanımlarını kolaylaştırdığını iddia etmektedir. Bu çerçevede DHA süreci öğrenenlerin kendi düşünce ve eylemlerini belirli bir düzen içerisinde tasarlayarak öğrenmelerini yansımalarına olanak tanımaktadır (Hull \& Nelson, 2005; Ivala, Gachago, Condy, \& Chigona, 2013).

Yansıtıcı düşünme ile ilgili çalışmalar incelendiğinde genel itibariyle yurt içi (Aydın \& Çelik, 2013; Bayrak \& Koçak-Usluel, 2011; Duban \& Yelken, 2010; Genç, 2016; Özçınar \& Deryakulu, 2011; Tok, 2008) ve yurt dışında yapılan çalışmaların (Kim \& Silver, 2016; H. J. Lee, 2005; I. Lee, 2007; Orland-Barak \& Yinon, 2007) önemli bir bölümünün öğretmen adaylarının yansıtıcı düşünme becerilerini anlamaya ve geliştirme ile yansıtıcı öğretim becerileri edinmelerine yönelik olduğu anlaşılmaktadır. K12 düzeyinde öğrenenlerin yansıtıcı düşünme becerisinin kazandırılması ya da geliştirilmesine yönelik çalışmaların ise sınırlı düzeyde kaldığı anlaşılmaktadır (Aryani, Rais, \& Wirawan, 2017; Baş \& Beyhan, 2012; Ersözlü \& Kazu, 2011).

\subsection{Dijital Hikaye Anlatımı ve Yansıtıcı Öğrenme}

Dijital hikaye anlatımı, geleneksel hikaye anlatımıyla metin, görsel, sesli anlatım, müzik ve video gibi çoklu-ortam unsurlarının birleştirilmesiyle oluşan kısa videolar olarak ifade edilebilir (Alismail, 2015; Barrett, 2008; Ivala et al., 2013; Robin, 2006, 2008; Rule, 2010). Dijital hikayeler bireysel ya da işbirlikli grup çalımasıyla oluşturulan, görsel ve ses unsurları gibi çoklu ortam unsurlarının bir araya getirildiği sanatsal bir etkinlik olarak da tanımlanabilir. Ayrıca, DHA; seçme, karşılaştırma, düzenleme, yaratma ve yeniden düzenleme gibi becerilerin kullanımını barındıran hikaye anlatımı ile teknolojiyi birleştiren öğrenci katılımını merkeze alan bir öğrenme etkinliğidir (Jenkins \& Lonsdale, 2007).

Hem öğretmen hem de öğrenen katılımını sağlayan dijital hikaye anlatımı örnek bir teknoloji entegrasyonu biçimidir (Dockter, Haug, \& Lewis, 2010). DHA'lar öğrenme sürecinde bir konuyu daha anlaşılır kılmak, özetlemek, konuyla ilgili tartışmaları kolaylaştırmak ya da yeni bir konunun öğretiminde kullanılmak amacıyla öğretmen tarafından hazırlanabilir ya da konuyla ilişkili hazır bir hikaye kullanılabilir. Genel olarak öğretmenlerin hazır çoklu ortamları tercih ettikleri söylenebilir. Bu bağlamda öğretmenler müfredat konularının öğretimi için güçlü bir öğrenme aracı olan ve zengin çoklu ortamlar içeren dijital hikayeler bulmak zorundadır (Campbell, 2012). Ancak öğretmenin dijital hikayeler sunmasından ziyade öğrencilere kendi dijital hikayeleme etkinliklerini oluşturmaları için fırsatlar sunulması çok daha faydalı olabilir (Robin, 2008). DHA'nın ikinci kullanımı öğrenilenleri yansıtmada farklı ve yeni bir yaklaşımdır ve öğrenme içeriğini anlamaya yardımcı olur. Böylelikle dijital hikayeleme etkinlikleri öğrencilerin 
öğrendiklerini yansımada ve derinlemesine öğrenme konusunda teşvik edici bir yapıya sahip olduğu ifade edilebilir (Ivala et al., 2013; Jenkins \& Lonsdale, 2007). Robin (2016) dijital hikaye anlatımı sürecinin öğrencilere öğrendiklerini yansıtmada yaratıcı ve kritik bir role sahip olduğunu ifade etmektedir.

Dijital hikaye anlatımının yansıtıcı öğrenme açısından en önemli unsuru olarak hikaye yazma sürecine hazırlık ve yazma basamağı "tanımlama, toplama ve karar verme" aşaması (Bkz. Şekil 1) olduğu söylenebilir. Benzer şekilde çeşitli çalışmalarda yazma aşamasının DHA sürecinin de önemli bir parçası olduğu belirtilmiştir (Lambert, 2013; Ohler, 2013; Robin, 2008). Hikaye yazarken öğrenenler farklı müfredat konularını yaratıcı ve açıklayıcı bir biçimde ele almakla birlikte çeşitli araştırma inceleme faaliyetleri ile sentez yapmaktadır. Hikayeyi oluşturmada yazma süreci kişinin kendi öğrenmeleriyle ilgili yansımalarını somutlaştırdığı için derinlemesine düşünmeyi gerektiren bir yapıya sahiptir (Ohler, 2013). Öğrenenler kendi dijital hikayelerini oluştururken eleştirel bir bakış açısı ve yansıtıcı düşünme becerilerini kullanarak hikaye karakterlerinin sorunlarının üstesinden gelmeleri için nihai kararlar alırlar (Benmayor, 2008; Malita \& Martin, 2010). Bu durumun da öğrencilerin yansıtıcı düşünme becerilerinin olumlu yönde gelişim göstermesine katkı sağladığı söylenebilir (Benmayor, 2008; Ivala et al., 2013; Malita \& Martin, 2010; Smeda et al., 2014; Yang \& Wu, 2012). Bireysel ya da işbirlikli olarak hazırlamış oldukları bu hikayelerini kısaltılarak senaryolaştıran öğrenenler, bu aşamada öğrenmelerini özetleme ve yansıtma açısından başka bir fırsat bulmuş olurlar. Bununla birlikte hikaye tahtası oluşturma, sesli anlatım ve nihayetinde oluşturulan dijital hikaye de birer yansıtıcı öğrenme aktivitesi olarak ele alınabilir. Ayrıca bu çalışmada kullanılan dersin çevrim-içi kısmında DHA'lar ile ilgili yürütülen tartışmalar ve öğrencilerin diğer arkadaşlarının hazırladıkları dijital hikayeleri değerlendirme ve yorumlama süreçlerinde de öğrendiklerini yansıma imkanı bulmuşlardır. Özetle DHA'nın öğrenenlerin öğrendiklerini yansımalarıyla ilgili detaylı ve anlamlı bilgi sağlayan bir yansıtıcı öğrenme süreci olduğu söylenebilir (Moseley, Gdovin, \& Jones, 2013; Nam, 2017). Dijital hikayeleme sürecinin yansıtıcı öğrenme sağlamada etkili bir yapıya sahip olmasının yanında problem çözme, yaratıcılık, eleştirel düşünme ve bilişim teknolojileri okuryazarlığı gibi çeşitli 21. yüzyıl yeterliklerinin kazandırılması ve geliştirilmesinde etkili olduğu alanyazında çalışmalarda sıklıkla vurgulanmaktadır (Niemi et al., 2014; Ohler, 2006; Robin, 2006, 2016; Sylvester \& Greenidge, 2009).

DHA etkinliklerinin yansıtıcı öğrenme deneyimi oluşturmadaki potansiyeli göz önünde bulundurulduğunda Sosyal Bilgiler dersinde öğrenenlerin yansıtıcı düşünme becerilerinin geliştirilmesine katkı sağlayacağı söylenebilir. Ancak, alanyazın incelendiğinde sosyal bilgiler dersinde DHA kullanımının yansıtıcı düşünme deneyimi sağlama ya da bu becerinin gelişimine katkı sağlanmasıyla ilişkili çalışmaların sınırlı düzeyde kaldığı görülmektedir. Bu bağlamda bu çalışmanın odağını dijital öyküleme etkinliklerinin ortaokul düzeyinde öğrenenlerin yansıtıcı düşünme becerileri üzerindeki etkilerinin incelenmesi oluşturmaktadır.

\subsection{Amaç}

Bu çalışmada sosyal bilgiler dersi ile bütünleştirilen dijital hikayeleme etkinliklerinin katılımcıların yansıtıcı düşünme becerilerilerinin gelişimi üzerindeki etkilerinin incelemesi olarak amaçlanmıştır. Bu amaç doğrultusunda aşağıdaki araştırma soruları cevaplandırılmıştır.

- Deney ve kontrol grubu öğrencilerinin yansıtıcı düşünme beceri düzeyleri nedir?

- Grupların ön-test yansıtıcı düşünme ölçeği puanlarına göre düzeltilmiş son-test puanları arasında anlamlı farklılık var mıdır?

- Grupların dersin çevrim-içi sayfasına katılım düzeylerine göre düzenlenmiş yansıtıcı düşünme ölçeği gelişim puanları arasında anlamlı farklılık var mıdır? 


\section{YÖNTEM}

\subsection{Araştırmanın Modeli}

Araştırmada yarı-deneysel yöntem kapsamında ön-test son-test kontrol gruplu desen kullanılmıştır. Çalışmanın modeline Tablo 1'de yer verilmiştir.

Tablo 1

Çalışmanın Yarı Deneysel Modeli

\begin{tabular}{|c|c|c|c|c|}
\hline Grup & & Ön-test & Uygulama & Son-test \\
\hline Grubu & $\mathrm{M}$ & $\mathrm{O}_{1}$ & $X$ & $\mathrm{O}_{1}$ \\
\hline Kontrol & $M$ & $\mathrm{O}_{2}$ & & $\mathrm{O}_{2}$ \\
\hline
\end{tabular}

$\begin{array}{lllll}\text { Uygulama } & 1 \mathrm{Hafta} & 1 \mathrm{Hafta} & 11 \mathrm{Hafta} & 1 \mathrm{Hafta}\end{array}$

$M \quad$ = Hazır grupların küme örneklemeyle atanması

$\mathrm{X}=$ Dijital Hikaye Anlatımı Etkinliği

$\mathrm{O}_{1.1}=$ Deney grubuna yönelik yansıtıcı düşünme ölçeği

$\mathrm{O}_{2.1} \quad=$ Kontrol grubuna yönelik yansıtıcı düşünme ölçeği

\section{2. Çalışma Grubu}

Uygulama 2016-2017 eğitim öğretim yılında Ankara ili Sincan ilçesinde bulunan bir ortaokulun 7. sınıf düzeyindeki iki sınıfında 11 hafta devam ettirilmiştir. Çalışma grubunu deney grubunda 33 ve kontrol grubunda 35 olmak üzere toplam 68 katılımcı oluşturmaktadır. Çalışma grubunun demografik özelliklerine ilişkin detaylı bilgiler Tablo 2'de sunulmuştur.

Tablo 2

Katılımcıların Demografik Özellikleri

\begin{tabular}{|c|c|c|c|c|}
\hline Değişkenler & & & $f$ & $\%$ \\
\hline \multirow{4}{*}{ Cinsiyet } & \multirow{2}{*}{ Deney Grubu } & Kız & 16 & 48.50 \\
\hline & & Erkek & 17 & 51.50 \\
\hline & \multirow{2}{*}{ Kontrol Grubu } & $\mathrm{K} ı \mathrm{Z}$ & 20 & 57.10 \\
\hline & & Erkek & 15 & 42.90 \\
\hline \multirow{8}{*}{ Anne Eğitim Düzeyi } & \multirow{4}{*}{ Deney Grubu } & ilkokul & 10 & 30.30 \\
\hline & & Ortaokul & 15 & 45.50 \\
\hline & & Lise & 7 & 21.20 \\
\hline & & Üniversite & 1 & 3.00 \\
\hline & \multirow{4}{*}{ Kontrol Grubu } & ilkokul & 16 & 45.70 \\
\hline & & Ortaokul & 10 & 28.60 \\
\hline & & Lise & 6 & 17.10 \\
\hline & & Üniversite & 3 & 8.60 \\
\hline \multirow{8}{*}{ Baba Eğitim Düzeyi } & \multirow{4}{*}{ Deney Grubu } & ilkokul & 4 & 12.10 \\
\hline & & Ortaokul & 7 & 21.20 \\
\hline & & Lise & 17 & 51.50 \\
\hline & & Üniversite & 5 & 15.20 \\
\hline & \multirow{4}{*}{ Kontrol Grubu } & ilkokul & 11 & 31.40 \\
\hline & & Ortaokul & 11 & 31.40 \\
\hline & & Lise & 11 & 31.40 \\
\hline & & Üniversite & 2 & 5.70 \\
\hline
\end{tabular}


Tablo 2'ye göre deney grubundaki öğrencilerin \%48.50'si kız ve \%51.50'si erkek öğrenciden oluşmakla birlikte kontrol grubundaki öğrencilerin \%57.10'nu kız ve \%42.90'nı erkek öğrenciden oluşmaktadır. Anne eğitim durumu bakımından dağılımlar incelendiğinde her iki grupta da katılımcı öğrencilerin annelerinin büyük bir bölümünün ilkokul ve ortaokul düzeyinde eğitim almış oldukları anlaşımaktadır. Tablo 2 'de sunulan baba eğitim düzeyiyle ilgili verilere göre deney grubu öğrencilerinin babalarının \%51.50'sinin lise ve sadece \%15.20'lik kısmının üniversite düzeyinde eğitim almış oldukları görülmektedir. Kontrol grubunda ise baba eğitim düzeyine göre katılımcıların babalarının \%31.40'nın ilkokul, \%31.40'nın ortaokul, \%31.40'nın lise ve \%5.70'nin üniversite mezunudur. Buna göre her iki grupta yer alan katılımcıların ebeveynlerinin eğitim seviyelerinin görece düşük olduğu söylenebilir.

\subsection{Uygulama}

\subsubsection{Kullanılan Araçlar}

Uygulama aşamasında deney ve kontrol grubunda kullanılan araçlar Tablo 3'te sunulmuştur.

Tablo 3.

Uygulama Sürecinde Gruplar Tarafından Kullanılan Çevrim-içi ve Masaüstü Araçları

\begin{tabular}{llll}
\hline \multicolumn{2}{c}{ Kontrol Grubu } & \multicolumn{2}{c}{ Deney Grubu } \\
\hline Çevrim-içi Araçlar & Masaüstü Araçları & Çevrim-içi Araçlar & Masaüstü Araçları \\
\hline Edmodo.com & Libre Office Writer & Edmodo.com & Paint \\
& Libre Office Impress & Storyboardthat.com & MS Office \\
& & & Powerpoint \\
& MS Office Word & Powtoon.com & Windows Live \\
& MS Office PowerPoint & & Movie Maker \\
& & & MS PhotoStory \\
\hline
\end{tabular}

Tablo 3'e göre bu çalışma kapsamında her iki grupta da dersin çevrim-içi bölümünde Edmodo kullanılmıştır. Çevrim-içi öğrenme ortamı ile deney ve kontrol grubu öğrencilerine ders sürecinde yararlanabilecekleri bazı kaynaklar sunulmuştur. Ayrıca her iki grupta yer alan öğrencilerin hazırlamış oldukları etkinlik ve ödevler çevrim-içi ortam aracılığıyla toplanmış ve bu ortam aracılığıyla bu ödev ve etkinliklere ders öğretmeni tarafından geribildirim sağlanmıştır. Bunun yanı sıra dersin çevrim-içi kısmı ile öğrencilere ders kapsamında duyurular yapılmıştır.

Deney grubu öğrencilerinin dijital hikayelerini oluştururken çeşitli çevrim-içi ve masa üstü araçları kullanmalarına olanak sağlanmıştır (Bkz.Tablo 3). Bu kapsamda hikaye tahtalarını dijital ortama aktarmak için Storyboardthat, Paint, MS PowerPoint; dijital hikaye oluşturma sürecinde ise masaüstü yazııımı olarak Windows Live Movie Maker ve MS PhotoStory sunulurken çevrim-içi olarak Powtoon aracı kullanımlarına olanak sağlanmıştır. Söz konusu araçların kullanımlarına ilişkin olarak dersin çevrim-içi kısmı aracılığıyla eğitici videolar paylaşılmıştır. Ayrıca kullanılan masaüstü araçlarının tamamı okul bilişim teknolojileri (BT) laboratuvarındaki tüm bilgisayarlara yüklenmiştir.

Uygulama aşamasında öğrenenlerin büyük bir çoğunluğunun hikaye tahtalarını dijital ortama aktarmak için Storyboardthat aracını kullandığı görülmüştür. Bunun en önemli sebebinin bu aracın çok sayıda görsel barındırması ve bunların özelleştirilebilmesi olduğu söylenebilir. Ayrıca BT sınıfında kullanılan internetin FATiH projesi kapsamında sunuluyor olması ve oldukça geniş sınırlamalara sahip olmasının öğrencilerin bu tercihinde etkili olduğu ifade edilebilir. Çoklu ortamların bir araya getirilerek dijital hikaye oluşturma sürecinde ise masaüstü araçlardan PhotoStory ve çevrim-içi Powtoon aracının ön plana çıktığı söylenebilir. PhotoStory aracında her bir sahnenin seslendirilmesinin ayrı ayrı yapılması ve ses ile görsel ya da videolarla 
senkronizasyonun otomatik olarak gerçekleştirilmesi daha fazla tercih edilmesine sebep olduğu ifade edilebilir.

Tablo 3'e göre kontrol grubunda öğrenenler araştırma ödevlerini hazırlama sürecinde, ödev raporlarını hazırlamak amacıyla Libre Office Writer, MS Office Word ve ödevleriyle ilgili sunumlarını hazırlamak amacıyla Libre Office Impress ve MS Office PowerPoint kullanmışlardır.

\subsubsection{Uygulama Öncesi Yapılanlar}

Uygulama öncesinde deney ve kontrol grubundaki öğrencilere eş zamanlı olarak "Yansıtıcı Düşünme Ölçeği" uygulanmıştır. Aynı hafta içerisinde her iki grupta yer alan öğrencilerin dersin çevrim-içi öğrenme ortamı olan Edmodo'ya kayıtları yapılmıştır. Sonrasında öğrenenlerle çevrim-içi ortamın kullanıma yönelik örnek etkinlikler gerçekleştirilmiştir. Bunu takiben deney grubunda DHA oluşturma aşamasında kullanılacak araçlarla ilgili öğrenciler bilgilendirilmiştir.

\subsubsection{Uygulama Süreci} sunulmuştur.

Uygulama sürecinde deney ve kontrol grubunda gerçekleştirilen işlemler Tablo 4'te

Tablo 4

Uygulama Sürecinde Deney ve Kontrol Grubunda Yapılan Işlemler

\begin{tabular}{|c|c|c|}
\hline Hafta & Deney Grubunda Gerçekleştirilen İşlemler & $\begin{array}{l}\text { Kontrol Grubunda Gerçekleştirilen } \\
\text { İşlemler }\end{array}$ \\
\hline $\mathrm{H} 1$ & $\begin{array}{l}\text { - Dijital hikayeleme etkinlikleriyle ilgili öğrenenlerin } \\
\text { bilgilendirilmesi } \\
\text { - Örnek DHA'ların incelenmesi } \\
\text { - } \quad \text { DHA oluşturma aşamalarıyla ilgili olarak öğrenenlerin } \\
\text { bilgilendirilmesi } \\
\begin{array}{l}\text { Tanımlama, toplama ve karar verme } \\
0\end{array} \quad \text { Senaryo ve hikaye tahtası oluşturma } \\
0 \quad \text { Resim ve ses dosyalarını seçme ve düzenleme } \\
\circ \quad \text { Kayıt yapma ve tanımlama } \\
\circ \quad \text { Gunma ve paylaşma } \\
\text { - } \quad \text { Grupların oluşturulması } \\
\text { - } \quad \text { Grup ve bireysel olarak konu dağıtımının gerçekleştirilmesi } \\
\text { - } \quad \text { Öğrencilerin dersin çevrim-içi ortamına kayıtlarının yapılması } \\
\text { - Çevrim-içi ortam aracılığıyla DHA oluşturma aşamalarında yer alan } \\
\text { araçların kullanımına ilişkin kaynak paylaşımının yapılması }\end{array}$ & 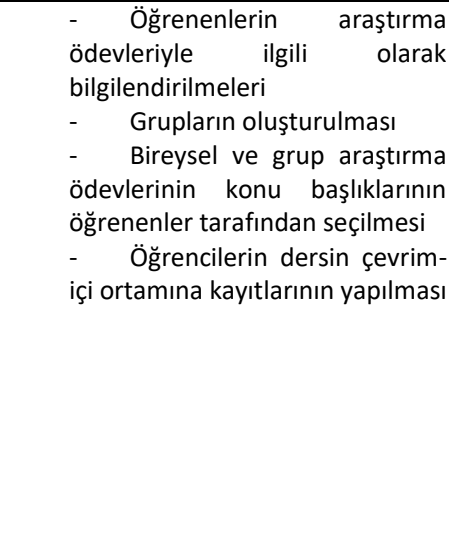 \\
\hline $\mathrm{H} 2$ & $\begin{array}{l}\text { Tanımlama, Toplama, Karar Verme } \\
\text { - Ders öğretmeni tarafından konu başlıklarıyla ilişkili kaynak } \\
\text { paylaşımı } \\
\text { - Öğrencilerin grup ödevleri kapsamında inceleme ve araştırma } \\
\text { işlemlerini yapması } \\
\text { - Grupların hikayelerini oluşturması ve dersin çevrim-içi sayfasına } \\
\text { yüklenmesi } \\
\text { - Hikayelerle ilgili öğretmenin geribildirim sunması } \\
\text { - } \quad \text { Geribildirim doğrultusunda grupların hikayesini güncellemesi }\end{array}$ & $\begin{array}{lrr}\text { - } & \text { Grupların seçmiş } & \text { oldukları } \\
\text { konu } \quad \text { başlıklarıyla } & \text { ilgili } \\
\text { araştırmaların yapılıması } & \end{array}$ \\
\hline $\mathrm{H} 3$ & $\begin{array}{l}\text { Senaryo ve Hikaye Tahtası Oluşturma } \\
-\quad \text { Hikayelerin kısaltılarak senaryolaştırılması } \\
-\quad \text { Hikaye tahtalarının oluşturulması } \\
\text { - Hazırlanana senaryo ve hikaye tahtaların dersin çevrim-içi } \\
\text { sayfasına yüklenmesi } \\
\text { - Sağlanan geribildirimler çerçevesinde hikaye tahtası ve } \\
\text { senaryoların güncellenmesi }\end{array}$ & $\begin{array}{l}\text { - Grupların araştırma } \\
\text { konularıyla ilgili taslak bir rapor } \\
\text { hazırlamaları } \\
\text { - Taslak raporun dersin } \\
\text { çevrim-içi ortama eklenmesi } \\
\text { - Taslak raporla iişkili olarak } \\
\text { ders öğretmenin geribildirimde } \\
\text { bulunması } \\
\text { - }\end{array}$ \\
\hline $\mathrm{H} 4$ & $\begin{array}{l}\text { Resim ve Ses Dosyalarını Seçme ve Düzenleme } \\
\text { - Hikaye tahtasına uygun olarak dijital ortamda sahnelerin } \\
\text { oluşturulması } \\
\text { - Her bir sahnede yer alacak senaryo metnin belirlenmesi } \\
\text { - } \quad \text { Arka plan müziğinin belirllenmesi ve düzenlenmesi }\end{array}$ & $\begin{array}{l}\text { - } \text { Araştırma raporuna son } \\
\text { biçiminin verilmesi ve dersin } \\
\text { çevrim-içi sayfasına yüklenmesi } \\
\text { - Grupların } \\
\begin{array}{l}\text { raporlarıyla ilgili sunumları } \\
\text { hazırlamaları }\end{array}\end{array}$ \\
\hline
\end{tabular}




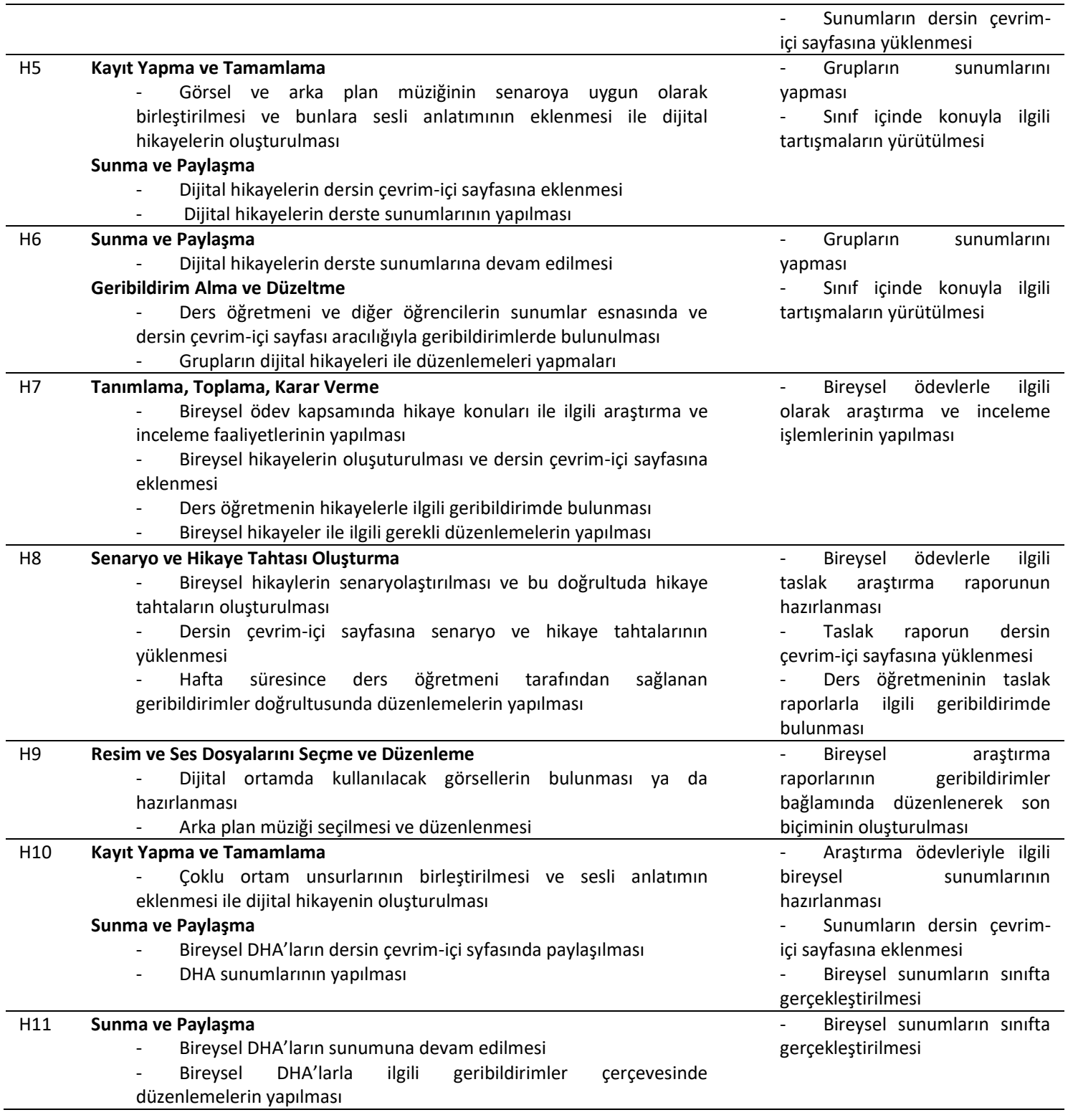

Uygulama aşamasında deney grubu öğrencilerine öncelikle dijital hikaye anlatımıyla ilgili bilgilendirme yapılmış ve örnek dijital hikayeler incelenmiştir (Bkz.Tablo 4). Bunu takiben Sarıtepeci ve Durak (2016) tarafından Robin (2008), Barret (2009) ve Morra (2013)'nın belirlemiş oldukları dijital hikaye anlatımı süreçleri incelenerek oluşturulan DHA aşamalarıyla ilgili olarak öğrencilerin bilgilendirilmesi sağlanmıştır (Bkz. Şekil 1). Öğrenenler bu DHA oluşturma sürecini takip ederek bir tanesi işbirlikli ve bir tanesi de bireysel olmak üzere iki farklı dijital hikaye oluşturmuşlardır. Katılımcılar DHA oluşturma sürecinin her bir adımında oluşturmuş oldukları ürünleri (hikaye, senaryo, hikaye tahtası, sahneler, sesli anlatım ve dijital hikaye) dersin çevrimiçi sayfası aracılığıyla ilgili göndermişlerdir. Ders öğretmeninin sağlamış olduğu geribildirimler doğrultusunda öğrenenler bu ürünlerle ilgili gerekli düzenlemeleri yapmışlardır. Katılımcılar hazırlamış oldukları dijital hikayeleri hazırlamış oldukları konu başlığının işlendiği derste sunmuşlardır. Bu sunum sonrasında ve çevrim-içi öğrenme ortamı aracılığıyla ders öğretmeni ve diğer öğrenciler tarafından sunulan geribildirimler doğrultusunda gerekli düzenlemeleri gerçekleştirmişlerdir. 


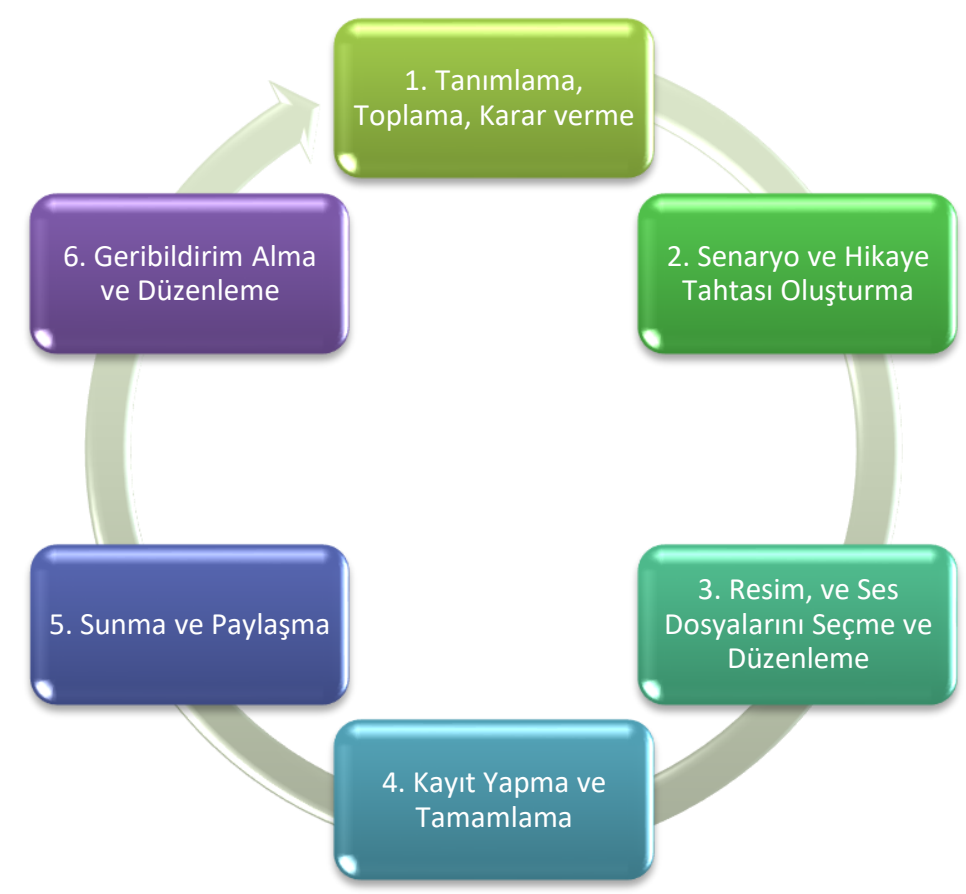

Şekil 1. Dijital Hikâye anlatımı Oluşturma aşamaları

Uygulama aşamasında kontrol grubunda yer alan öğrencilere yansıtıcı öğrenme deneyimi sağlamak adına ilgili ünite altında yer alan konu başlıklarıyla ilişkili olarak iki farklı araştırma ödevi verilmiştir (Bkz. Tablo 4). Öğrenenler bu ödevlerden ilkini işbirlikli olarak iki kişilik gruplar halinde oluşturmuşlardır. İkinci konu başlığıyla ilişkili ödevi ise bireysel olarak hazırlamışlardır. Hazırladıkları ödevleriyle ilgili olarak hazırladıkları özet raporları ilgili derste sunmuşlardır.

\subsection{Verilerin Toplanması}

Veri toplama aracı olarak Yıldırım (2012)'ın ortaokul öğrencilerine yönelik olarak hazırlamış olduğu "Yansıtıcı Düşünme Ölçeği" kullanıımıştır. Aynı çalışmada ölçeğin hesaplanan güvenirlik katsayısının 86 olduğu belirlenmiştir. Yansıtıcı düşünme ölçeği tek faktörlü bir yapıya sahip olup 17 maddeden oluşmaktadır. Ölçek her iki gruba da uygulama öncesi ve sonrasında eş zamanlı olarak uygulanmıştır.

\subsection{Veri Analizi}

Katılımcıların veri toplama aracına vermiş oldukları cevaplardan elde edilen verilerin dağılımı incelenmiş ve kontrol grubunda ön-test ve son-testte uç değerler oluşturan iki kişiden elde edilen veriler analiz sürecine dahil edilmemiştir. Grupların ön-test ve son-test olarak uygulanan yansıtıcı düşünme ölçeğinden elde ettikleri puanların karşılaştırılmasında kovaryans analizi (ANCOVA) kullanılmıştır. Öncelikle ANCOVA analizinin gerçekleştirilmesi için veri setinin gerekli varsayımları sağlayıp sağlamadığının tespiti yapılmıştır. Bu çerçevede ANCOVA varsayımları açısından veriler incelendiğinde; (1) her iki grup düzeyinde ön-test ve son-test puanlarının dağılımının Shapiro-Wilks testine göre normal dağılıma sahip olduğu, (2) grupların varyanslarının homojen olduğu, (3) her iki grup düzeyinde bağımlı değişken ile kontrol değişkeni arasında aynı yönlü bir ilişki olduğu, (4) gruplar-içi regresyon doğrularının eğimlerinin eşliği varsayımının karşılandığı belirlenmiştir.

Her iki grubun dersin çevrim-içi sayfasında gerçekleştirmiş oldukları etkinlik/ödev sayısına göre yansıtıcı düşünme becerilerindeki gelişim düzeyinin karşılaştırılmasında kovaryans 
analizi kullanılmıştır. Verilerin dağılımının ANCOVA vasayımlarını karşılama durumu incelendiğinde; (1) her iki grup öğrencilerinin çevrim-içi ortamda gerçekleştirdikleri etkinlik/ödev sayıları ve gelişim puanlarının normal dağılıma sahip oldukları, (2) grupların varyanslarının eşit olduğu, (3) deney ve kontrol grubu düzeyinde çevrim-içi etkinlik/ödev sayısı ile yansıtıcı düşünme beceri ölçeği puanlarının gelişimi arasında aynı yönlü ilişki olduğu ve (4) grup-içi regresyon eğimlerinin eşit olduğu belirlenmiştir.

\section{BULGULAR}

\subsection{Deney ve kontrol grubunun yansıtıcı düşünme beceri düzeylerine ilişkin bulgular}

Birinci araştırma sorusu kapsamında deney ve kontrol gruplarının yansıtıcı düşünme ölçeği gelişim puanları son-test puanları ile ön-test puanlarının farkı alınarak hesaplanmış olup grupların yansıtıcı düşünme ölçeği ön-test, son-test ve gelişim puanları ile ilgili betimsel bulgulara Tablo 5'te yer verilmiştir.

Tablo 5. istatistikler

Grupların Yansıtıcı Düşünme Ölçeği Ön-test ve Son-test Puanlarına ilişkin Betimsel

\begin{tabular}{lllllll}
\hline Grup & Test & $\mathrm{N}$ & $\bar{X}$ & sd & Min. & Maks. \\
\hline \multirow{3}{*}{ Kontrol Grubu } & Ön-test & 33 & 3.61 & .38 & 2.35 & 4.38 \\
& Son-test & 33 & 3.69 & .39 & 2.29 & 4.59 \\
& Gelişim Puanı & 33 & .08 & .27 & -.64 & .47 \\
\hline \multirow{3}{*}{ Deney Grubu } & Ön-test & 33 & 3.31 & .44 & 2.59 & 4.53 \\
& Son-test & 33 & 3.83 & .39 & 3.12 & 4.65 \\
& Gelişim Puanı & 33 & .53 & .40 & -.18 & 1.41 \\
\hline
\end{tabular}

Tablo 5 'te sunulan veriler incelendiğinde deney grubunun uygulama öncesi yansıtıcı düşünme ölçeği puanı 3.31 iken kontrol grubunun puanı 3.61 olarak gerçekleşmiştir. Uyulama sonrasında gerçekleştirilen son-testte deney grubunun yansıtıcı düşünme ölçeği puanı 3.83, kontrol grubununki ise 3.69 olarak bulunmuştur. Bu bulgulara göre deney grubunun yansıtıcı düşünme ölçeği gelişim puanı .53 , kontrol grubununki ise .08 olarak hesaplanmıştır. Her iki grupta yansıtıcı düşünme beceri düzeylerindeki gelişim Şekil 2'de sunulmuştur.

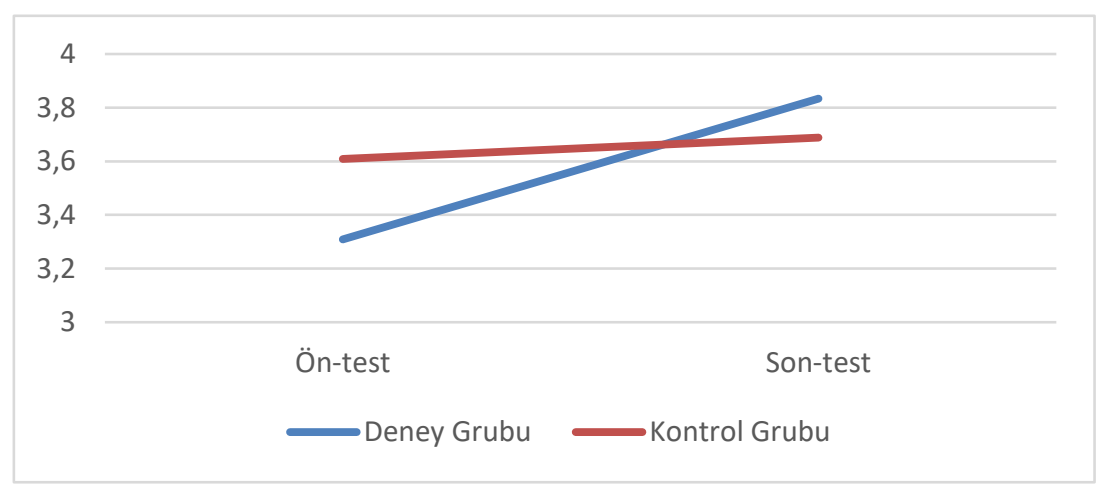

Şekil 2. Deney ve Kontrol Grubundaki Katılımcıların Yansıtıcı Düşünme Ölçeği Puanlarındaki Değişim

Uygulama öncesine göre yansıtıcı öğrenme becerisindeki gelişim Şekil 2' de daha açık bir biçimde gözlemlenmektedir. Uygulama öncesine göre uygulama sonrasında kontrol grubu öğrencilerinin yansıtııı düşünme ölçeği puanlarındaki gelişim nispeten daha sınırlı düzeyde 
kalmıştır. Deney grubu öğrencilerinin yansıtıcı düşünme becerilerindeki gelişimin kontrol grubuna göre daha yüksek olduğu anlaşılmaktadır.

\subsection{Grupların Ön-Test Yansıtıcı Düşünme Ölçeği Puanlarına Göre Düzeltilmiş Son-Test Puanlarının Karşılaştıtılması}

Dijital öykülemenin katılımcıların yansıtıcı düşünme becerilerine etkilerinin incelendiği bu çalışmada "Yansıtıcı Düşünme Ölçeği" çalışma gruplarına ön-test ve son-test olarak uygulanmıştır. Ön-test puanlarına göre grupların düzeltilmiş son-test yansıtıcı düşünme ölçeği puanlarının karşılaştırılmasında tek faktörlü kovaryans analizi gerçekleştirilmiş olup düzeltilmiş son-test puanlarıyla ilgili betimsel istatistiki bilgilere Tablo 6 'da yer verilmiştir.

Tablo 6

Yansıtııı Düşünme Ölçeği Düzeltilmiş Son-test Ortalama Puanları

\begin{tabular}{lllllc}
\hline Gruplar & & $\mathbf{N}$ & $\overline{\boldsymbol{X}}$ & sd & Düzeltilmiş $\overline{\boldsymbol{X}}$ \\
\hline Kontrol & Son-test & 33 & 3.70 & .27 & 3.62 \\
Deney & Son-test & 33 & 3.83 & .39 & 3.92 \\
\hline
\end{tabular}

Tablo 6 incelendiğinde kontrol grubunun son-test puanı 3.70 iken yansıtıcı düşünme ölçeği ön-test puanlarına göre düzeltilmiş son-test puanı 3.62 olarak bulunmuştur. Deney grubunda ise son-test puanı 3.83 iken düzeltilmiş son-test puanı 3.92'dir. Deney ve kontrol grubunun düzeltilmiş son-test puanlarının karşılaştırılmasına ilişkin bulgular Tablo 7'de sunulmuştur.

Tablo 7.

Deney ve Kontrol Gruplarının Düzeltilmiş Son-test Yansıtıcı Düşünme Ölçeği Puanlarının Karşılaştırılması

\begin{tabular}{lccccc}
\hline $\begin{array}{l}\text { Varyansın } \\
\text { Kaynağı }\end{array}$ & Kareler Toplamı & df & Kareler Ortalaması & F & $\mathbf{p}$ \\
\hline Ön-test (Reg.) & 2.25 & 1 & 2.25 & 29.33 & .00 \\
Grup & $\mathbf{1 . 1 9}$ & $\mathbf{1}$ & $\mathbf{1 . 1 9}$ & $\mathbf{1 5 . 4 7}$ & $\mathbf{. 0 0}$ \\
Hata & 4.84 & 63 & & & \\
Toplam & 7.37 & 65 & & & \\
\hline
\end{tabular}

Tablo 7'de sunulan ANCOVA analizine göre ön-test yansıtıcı düşünme ölçeği puanlarına göre düzeltilmiş son-test puanları arasında deney grubu lehine anlamlı farklılık oluşmuştur $[F(1,62)=15.47, p<.05]$. Deney ve kontrol grubunun ön-teste göre düzeltilmiş son-test puanları arasında gerçekleştirilen Bonferroni testi sonucuna göre deney grubundaki katılımcıların yansıtıcı düşünme algıları ( $\bar{x}=3.92)$ kontrol grubu katılımcılarınkinden $(\bar{x}=3.62)$ daha yüksektir. Bu bulguya göre DHA'nın yansıtıcı düşünme becerisini geliştirmede dikkate değer bir etkiye sahip olduğu ifade edilebilir.

3.3. Grupların Dersin Çevrim-içi Sayfasına Katılım Düzeylerine Göre Düzenlenmiş Yansıtıcı Düşünme Ölçeği Gelişim Puanlarının Karşılaştırılması

Öğrencilerin dersin çevrim-içi sayfasına katılım düzeyleri, öğrencilerin çevrim-içi ortamda (edmodo) gerçekleştirdikleri etkinlik/ödev sayısına göre belirlenmiştir. Öğrenci etkinlik/ödev sayısı her iki grupta da öğrencilerin hazırlamış oldukları etkinlik/ödev ile bu etkinlik/ödevlerle ilgili gerçekleştirmiş oldukları güncellemeleri içermektedir. Her iki grup düzeyinde çevrim-içi etkinliklere katılım düzeyine göre düzeltilmiş yansıtıcı düşünme becerisi ölçeği gelişim puanlarının karşılaştırılmasında tek faktörlü kovaryans analizi gerçekleştirilmiş olup düzeltilmiş yanstıcı düşünme ölçeği gelişim puanlarıyla ilişkili betimsel istatistiki bilgiler Tablo 8' de sunulmuştur. 
Tablo 8

Yansıtıcı Düşünme Ölçeği Düzeltilmiş Son-test Ortalama Puanları

\begin{tabular}{|c|c|c|c|c|c|}
\hline Gruplar & & $\mathbf{N}$ & $\bar{X}$ & sd & Düzeltilmiş $\bar{X}$ \\
\hline Kontrol & Gelişim Puanları & 33 & .08 & .27 & 14 \\
\hline Deney & Gelişim Puanları & 33 & .53 & .40 & .45 \\
\hline
\end{tabular}

Tablo 8'e göre kontrol grubu öğrencilerinin yansıtıcı düşünme ölçeği gelişim puanı .08 olarak bulunurken çevrim-içi ortamda gerçekleştirilen etkinilik/ödev sayısına göre düzeltilmiş yansıtıcı düşünme ölçeği gelişim puanı .14 olarak bulunmuştur. Deney grubunun ise gelişim puanı .53 iken, çevrim-içi etkinliklere (Edmodo) katılım düzeyine göre düzenlenmiş gelişim puanı .45 olarak bulunmuştur. Grupların Edmodo etkinliklerine katılım düzeylerine göre düzeltilmiş yansıtıcı düşünme beceri ölçeği gelişimi puanlarının karşılaştırılmasına ilişkin ANCOVA analiz sonuçları Tablo 9'da verilmiştir.

Tablo 9.

Deney ve Kontrol Gruplarının Edmodo Etkinliklerine Katılım Durumuna Göre Düzeltilmiş Son-test Yansıtıcı Düşünme Ölçeği Puanlarının Karşılaştırılması

\begin{tabular}{lccccc}
\hline $\begin{array}{l}\text { Varyansın } \\
\text { Kaynağı }\end{array}$ & Kareler Toplamı & $\mathbf{d f}$ & Kareler Ortalaması & $\mathbf{F}$ & $\mathbf{p}$ \\
\hline Edmodo (Reg.) & 2.08 & 1 & 2.08 & 25.65 & .00 \\
Grup & $\mathbf{1 . 3 1}$ & $\mathbf{1}$ & $\mathbf{1 . 3 1}$ & $\mathbf{1 6 . 1 6}$ & $\mathbf{. 0 0}$ \\
Hata & 5.12 & 63 & .08 & & \\
Toplam & 10.70 & 65 & & & \\
\hline
\end{tabular}

Tablo 9'a göre Edmodo ortamında katılımcıların gerçekleştirmiş oldukları ödev/etkinlik sayısı istatistiksel olarak anlamlı düzeyde yantısıtıcı düşünme ölçeği gelişim puanlarıyla ilişkili olduğu anlaşılmaktadır $[F(1,162)=25.65, p<.05]$. Ayrıca çevrim-içi öğrenme ortamında gerçekleştirilen etkinlik/ödev sayısına göre düzeltilmiş yansıtıcı düşünme ölçeği gelişim puanları karşılaştıııldığında grup düzeyinde anlamlı farklılık oluşmuştur $[F(1,162)=16.16, p<.05]$. Elde edilen bulgulara göre çevrim-içi öğrenme ortamında gerçekleştirilen ödev/etkinlik sayısı öğrenenlerin yansıtıcı düşünme becerisilerinin gelişimi üzerinde etkili olduğu söylenebilir. Bununla birlikte çevrim-içi ortamda ödev/etkinlik sayısına göre düzenlenmiş gelşim puanları incelendiğinde dijital hikayeleme etkinliklerinin yansıtıcı düşünme becerisi üzerinde etkili olduğu belirlenmiştir.

\section{SONUÇ, TARTIŞMA VE ÖNERILER}

Bu çalışma kapsamında sosyal bilgiler dersi müfredatıyla bütünleştirilen dijital öyküleme etkinliklerinin öğrendiklerini yansıma üzerindeki etkilerini incelemek amaçlanmıştır. Bu amaç kapsamında yarı deneysel desen kullanılan bu çalışmada kontrol grubunda derste araştırmainceleme ödevlerine yer verilirken deney grubunda derste dijital öyküleme etkinliklerine yer almıştır.

Çalışmanın bulgularına göre dijital öyküleme etkinliklerinin Sosyal Bilgiler dersinde yansıtıcı düşünme becerisini geliştirmede etkili olduğu sonucuna ulaşılmıştır. Bu tespitle ilgili olarak Barret (2006) dijital hikayeleme etkinliklerinin öğrenen merkezli stratejilerden öğrenen katılımı, derinlemesi bilgi edinmek için yansıtıcı öğrenme, proje temelli öğrenme ve teknoloji entegrasyonu stratejisini birleştirmeye olanak tanıyan bir yapıya sahip olduğunu belirtmektedir. DHA'nın yansıtıcı öğrenmeyi desteklemesiyle alakalı Matthews-DeNatale (2008) dijital öykü oluşturma sürecinin klasik ödev ya da etkinlikler (yazılı ya da basılı) aracılığıyla sağlanması 
oldukça güç olan bir yansıtıcı öğrenmeye olanak tanıdığını ifade etmektedirler. Bunu destekler biçimde bu çalışmada deney grubunda DHA kapsamında öğrenenlere dağıtılan konu başlıkları, kontrol grubunda yer alan öğrenenlere yansıtıcı öğrenme çerçevesinde araştırma ödevleri olarak verilmiş ve bu ödevlerle ilişkili olarak hazırladıkları ürünleri yeri geldiğinde sınıf içerisinde sunmalarına olanak sağlanmasına rağmen katılımcıların yansıtıcı düşünme becerilerinin gelişimi sınırlı düzeyde kalmıştır. Burada oluşan bu farklıı̆ı̆n temelinde klasik ödevlerin öğrenenlerin ilgisini çekmemesi ve bunun doğal bir sonucu olarak bu gibi ödev ve etkinliklerin öğrenenler tarafından sadece bir zorunluluk olarak yapılmasından kaynaklandığı söylenebilir. Bu durumunda ödevlere karşı öğrenenlerin olumsuz bir tutum edinmelerine sebep olduğu iddia edilebilir (Duru \& Çöğmen, 2017). DHA gibi öğrenenin yaratıcılı̆ını ve üretim temelli teknoloji kullanımını destekleyen etkinliklerde ise öğrenen ilgisi ve katılımının üst düzeyde gerçekleştiği söylenebilir (Sarıtepeci \& Çakır, 2017).

Bu çalışmadan farklı olarak Bayrak ve Koçak-Usluel (2011) araştırmalarında üretim temelli teknoloji kullanımı bağlamında ağ günlüklerinin yansıtıcı düşünme becerisi üzerinde etkisinin sınırlı düzeyde kaldığı sonucuna ulaşmışlardır. İki çalışma arasında oluşan bu farklılığın birkaç farklı sebepten kaynaklandığı söylenebilir. (1) Bayrak ve Koçak-Usluel (2011) uygulama sürecinde öğrenenlerin ağ günlüklerine katılımlarında düşüş yaşanmasının yansıtıcı düşünme becerisinde önemli bir farklılık oluşmamasının temel sebebi olarak görmektedirler. Bu çalışmada ise katılımcıların dijital hikayeleme etkinliklerine genel olarak katılımlarında önemli bir değişim olmadığı gözlemlenmiştir. Bu durumda katılımcıların yansıtıcı düşünme becerisini geliştirmeye dönük daha fazla etkinlik içerisinde bulunmalarını sağlamıştır. (2) ỉki çalışma arasındaki bir diğer önemli farklılık ise katılımcıların devam ettikleri öğretim düzeyidir. Bayrak ve Koçak-Usluel'in (2011) çalışmalarında katılımcılar lisans düzeyinde, bu çalışmada ise ortaokul seviyesindedir. Çalışma gruplarının eğitim düzeyi çalışmaların bulguları arasındaki farklılığı açıklayabilecek bir diğer unsurdur. Çünkü öğrenme-öğretme ortamlarının teknoloji ile bütünleştirilmesinin ortaöğretim ya da yüksek öğretime göre ilk ve ortaokul düzeyinde daha olumlu çıktıları olduğu alanyazında vurgulanan bir durumdur (Saritepeci \& Cakir, 2015; Senemoglu, 2010). Bunu destekler biçimde Ersözlü ve Kazu (2011) çalışmalarında ortaokul 5. sınıf düzeyinde yansıtıcı düşünme becerisini geliştiren etkinlikler çerçevesinde ağ günlüğü ve sorgulama stratejilerinin kullanımının öğrencilerin kavrama, uygulama ve analiz düzeylerinde etkili olduğu sonucuna ulaşmışlardır. (3) Bir diğer sebep ise DHA sürecinin ağ günlüklerine oranla yansıtıcı düşünme becerisini geliştirmeye yönelik daha fazla olanak sunduğu (hikaye, hikaye tahtası, dijital hikaye oluşturma vb.) da ifade edilebilir.

Çevrim-içi öğrenme etkinliklerine/ödevlere katılım düzeyi ile yansıtıcı düşünme becerisinin gelişimi arasında anlamlı ilişki olduğu tespit edilmiştir. Buna göre katılımcıların dersin çevrim-içi öğrenme ortamında gerçekleştirdikleri etkinlik/ödev sayısı yansıtıcı düşünme becerisinin gelişimi üzerinde olumlu etkisi olduğu söylenebilir. Bununla birlikte grupların çevrimiçi öğrenme ortamında gerçekleştirilen etkinlik/ödev sayısına göre düzenlenmiş yansıtıcı düşünme ölçeği gelişim puanları arasında DHA etkinlikleriyle bütünleştirilen derse katılan deney grubu lehine anlamlı fark oluştuğu görülmektedir. Buna göre dijital hikaye anlatımı kapsamında gerçekleştirilen etkinliklerin yansıtıcı düşünme becerisinin geliştirilmesinde dikkate değer bir etkiye sahip olduğu sonucuna ulaşılmıştır. Çevrim-içi öğrenme-öğretme ortamlarında sunulan etkinliklerin, dijital hikayelemeyle ilgili etkinliklerde olduğu gibi, yansıtcı düşünmenin gelişimine katkı sağlayabilmeleri için gerçek hayat durumlarıyla ilişkili ve öğrenen katılımını destekleyici bir yapıda olması gerektiği ifade edilebilir. Bunu destekler biçimde Baş ve Beyhan (2012) çevrim-içi öğrenme ortamlarında sunulan etkinliklerin öğrenme ihtiyaçlarına yönelik ve gerçek yaşam durumlarıyla ilişkili olması ve bu etkinliklerin öğrencilerin katılımını destekleyecek unsurları içerecek biçimde planlanmasının yansıtıcı öğrenmeyi olanaklı kıldığını vurgulamaktadırlar. 
DHA etkinlikleri süresince öğrenenler farklı aşamalarda öğrenmeleriyle ilgili yansıma olanakları bulmaktadırlar. Bunlardan belki de en önemlisi bir konu başlığıyla ilgili araştırma ve inceleme faaliyetlerini takip eden hikâye yazma aşamasıdır. Bu aşamada katılımcı belirli bir kurgu çerçevesinde kendi bilgi yapılandırma sürecinde edindiği deneyime bağlı olarak bir öykü yaratır. Öğrendiklerini kendince bir organizasyon çerçevesinde yansıma olanağı bulduğu bu aşama belki de DHA sürecinin yansıtıcı düşünme becerisini geliştirme de en önemli kısmı olduğu ifade edilebilir. Bu tespiti destekler biçimde yansıtıc düşünme becerisinin geliştirilmesinde yazma sürecinin olumlu etkisi üzerinde bir uzlaşı söz konusudur (Arslan, 2017; Baş \& Beyhan, 2012; Tok, 2008; Wilson \& Jan, 1993). Burada ifade edilen yazma sürecinin niteliğiyle ilgili olarak Kızılkaya ve Aşkar (2009) öğrenenlerin yazma sürecinde hangi aşamada ne yaptıklarını ve bunu nasıl yaptıklarını sorgulamaları ve gerçekleştirdikleri etkinliklerle ilgili sergiledikleri performansla alakalalı farkındalık edinebilmeleri gerektiğini ifade etmektedir. Sorgulama ve yaratıcılık süreçlerini içermeyen bir yazma faaliyetinin yansıtıcı düşünme üzerinde çok önemli etkileri olmayacağı ifade edilebilir. Yansıtıcı yazma faaliyetlerinin öğrendiklerini yansımada sağladığı avantajlar göz önünde bulundurulduğunda geleneksel hikaye anlatımı yöntemi ile dijital hikaye anlatımının benzer öğretim süreçlerinde yansıtıcı düşünme becerisinin gelişimi üzerindeki etkilerinin incelendiği çalışmalar gerçekleştirilebilir. Böylelikle geleneksel hikaye anlatımına çoklu ortam unsurlarının eklenerek zenginleştirildiği DHA etkinliklerinin yansıtıcı öğrenme süreçlerine katkıları daha geniş çaplı ortaya konulabilir.

\section{KAYNAKLAR}

Alismail, H. A. (2015). Integrate Digital Storytelling in Education. Journal of Education and Practice, 6(9), 126-129.

Alkan, C. K. M. (1998). Özel Öğretim Yöntemleri. Ankara: Anı Yayıncılık.

Altınışık, S., \& Orhan, F. (2002). Sosyal bilgiler dersinde çoklu ortamın öğrencilerin akademik başarıları ve derse karşı tutumları üzerindeki etkisi. . Hacettepe Üniversitesi Eğitim Fakültesi Dergisi, 23(23).

Arslan, M. M. (2017). Adayların yansıtıcı günlüklerinde öğretmenlik uygulamasına yönelik farkındalıkları. Bartın Üniversitesi Eğitim Fakültesi Dergisi, 6(3), 1017-1026.

Aryani, F., Rais, M., \& Wirawan, H. (2017). Reflective learning model in improving student critical thinking skills. Global Journal of Engineering Education, 19(1), 19-23.

Aydın, M., \& Çelik, T. (2013). Sosyal bilgiler öğretmen adaylarının yansıtıcı düşünme becerilerinin bazı değişkenler açısından incelenmesi. Pamukkale Üniversitesi Eğitim Fakültesi Dergisi, 34(34), 169-131.

Barrett, H. C. (2006). Researching and evaluating digital storytelling as a deep learning tool. Technology and teacher education annual, 1, 647.

Barrett, H. C. (2008). Multiple purposes of digital stories in ePortfolios. Paper presented at the Society for Information Technology \& Teacher Education International Conference.

Barrett, H. C. (2009). How to create simple digital stories.

Baş, G., \& Beyhan, Ö. (2012). İngilizce dersinde yansıtıcı düşünme etkinliklerinin öğrencilerin akademik başarılarına ve derse yönelik tutumlarına etkisi. Amasya Üniversitesi Ĕgitim Fakültesi Dergisi, 1(2), 128-142.

Bayrak, F., \& Koçak-Usluel, Y. (2011). Ağ günlük uygulamasının yansıtıcı düşünme becerisi üzerine etkisi. Hacettepe Üniversitesi Eğitim Fakültesi Dergisi, 40(40). 
Benmayor, R. (2008). Digital storytelling as a signature pedagogy for the new humanities. Arts and Humanities in Higher Education, 7(2), 188-204.

Campbell, T. A. (2012). Digital storytelling in an elementary classroom: Going beyond entertainment. Procedia-Social and Behavioral Sciences, 69, 385-393.

Dewey, J. (1933). How we think: Courier Corporation.

Dockter, J., Haug, D., \& Lewis, C. (2010). Redefining rigor: Critical engagement, digital media, and the new English/language arts. Journal of Adolescent \& Adult Literacy, 53(5), 418-420.

Duban, N., \& Yelken, T. Y. (2010). Öğretmen adaylarının yansıtıcı düşünme eğilimleri ve yansıtıcı öğretmen özellikleriyle ilgili görüşleri. Çukurova Üniversitesi Sosyal Bilimler Enstitüsü Dergisi, 19(2).

Duru, S., \& Çöğmen, S. (2017). Illkokul-Ortaokul Öğrencileri ve Velilerin Ev Ödevlerine Yönelik Görüşleri. Illköğretim Online, 16(1).

Ersözlü, Z. N., \& Kazu, H. (2011). İlköğretim beşinci sınıf sosyal bilgiler dersinde uygulanan yansıtıcı düşünmeyi geliştirme etkinliklerinin akademik başarıya etkisi. Uludağ Üniversitesi Eğitim Fakültesi Dergisi, 24(1).

Genç, M. A. (2016). Evaluation of Gifted and Talented Students' Reflective Thinking in Visual Arts Course. Universal Journal of Educational Research, 4(9), 20392048.

Hull, G. A., \& Nelson, M. E. (2005). Locating the semiotic power of multimodality. Written communication, 22(2), 224-261.

Ivala, E., Gachago, D., Condy, J., \& Chigona, A. (2013). Digital storytelling and reflection in Higher Education: A case of pre-service student teachers and their lecturers at a University of Technology. Journal of Education and Training Studies, 2(1), 217-227.

Jenkins, M., \& Lonsdale, J. (2007). Evaluating the effectiveness of digital storytelling for student reflection. Paper presented at the ICT: Providing choices for learners and learning. Proceedings ASCILITE Singapore 2007.

Karaoglan-Yilmaz, F. G., \& Keser, H. (2016). The impact of reflective thinking activities in e-learning: A critical review of the empirical research. Computers \& Education, 95, 163-173.

Kim, Y., \& Silver, R. E. (2016). Provoking reflective thinking in post observation conversations. Journal of Teacher Education, 67(3), 203-219.

Kızılkaya, G., \& Aşkar, P. (2009). Problem çözmeye yönelik yansıtıcı düşünme becerisi ölçeğinin geliştirilmesi. Egitim ve Bilim, 34(154).

Lai, T. L., \& Land, S. M. (2009). Supporting reflection in online learning environments. In Educational media and technology yearbook (pp. 141-154). Springer US.

Lee, H. J. (2005). Understanding and assessing preservice teachers' reflective thinking. Teaching and Teacher Education, 21(6), 699-715.

Lee, I. (2007). Preparing pre-service English teachers for reflective practice. ELT journal, 61(4), 321-329.

Malita, L., \& Martin, C. (2010). Digital storytelling as web passport to success in the 21st century. Procedia-Social and Behavioral Sciences, 2(2), 3060-3064.

Matthews-DeNatale, G. (2008). Digital Storytelling: tips and resources. Boston: Simmons College. Retrieved January, 16, 2015.

Morra, S. (2013). Steps to great digital storytelling. Edtechteacher. URL: http://edtechteacher. org/8-steps-to-great-digitalstorytelling-from-samantha-onedudemic.

Moseley, C., Gdovin, R., \& Jones, K. (2013). Exploring mental models of science teachers using digital storytelling. European Journal of Science Education, 17, 1-20. 
Nam, C. W. (2017). The effects of digital storytelling on student achievement, social presence, and attitude in online collaborative learning environments. Interactive Learning Environments, 25(3), 412-427.

Neo, M., \& Neo, T. K. (2010). Students' perceptions in developing a multimedia project within a constructivist learning environment: A Malaysian experience. Turkish Online Journal of Educational Technology, 9(1), 176-184.

Niemi, H., Harju, V., Vivitsou, M., Viitanen, K., Multisilta, J., \& Kuokkanen, A. (2014). Digital storytelling for 21st-century skills in virtual learning environments. Creative Education, 5(9), 657.

Ohler, J. (2006). The world of digital storytelling. Educational leadership, 63(4), 44-47.

Orland-Barak, L., \& Yinon, H. (2007). When theory meets practice: What student teachers learn from guided reflection on their own classroom discourse. Teaching and Teacher Education, 23(6), 957-969.

Özçınar, H., \& Deryakulu, D. (2011). Video-durumlarda yansıma noktalarının ve tartışma gruplarında öğretmen katılımının yansıtıcı düşünmeye etkisi. Hacettepe Üniversitesi Eğitim Fakültesi Dergisi, 40(40).

Partnership for 21st Century Skills (P21), (2007). Partnership for 21st Century Skills. http://www.p21.org/about-us/p21-framework/60sayfasından erişilmiştir.

Prensky, M. (2001). Digital natives, digital immigrants part 1. On the horizon, 9(5), 1-6.

Robin, B. (2006). The educational uses of digital storytelling. Technology and teacher education annual, 1, 709.

Robin, B. (2008). Digital storytelling: A powerful technology tool for the 21st century classroom. Theory Into Practice, 47(3), 220-228.

Robin, B. (2016). The Power of Digital Storytelling to Support Teaching and Learning. Digital Education Review, 30, 17-29.

Rule, L. (2010). Digital storytelling: Never has storytelling been so easy or so powerful. Knowledge Quest, 38(4), 56.

Saritepeci, M., \& Cakir, H. (2015). The Effect of Blended Learning Environments on Student's Academic Achievement and Student Engagement: A Study on Social Studies Course. Egitim Ve Bilim-Education and Science, 40(177), 203-216. doi:10.15390/EB.2015.2592

Sarıtepeci, M., \& Çakır, H. (2017). Examining Perceived Satisfaction Related to the Digital Storytelling Process. Paper presented at the EdMedia 2017 Washington, DC, United States.

Sarıtepeci, M., \& Durak, H. (2016). Bilgi teknolojilerinin temelleri ünitesinin işlenmesinde dijital hikâye anlatımı kullanımının öğrenen motivasyonuna etkisi. Eğitim ve Öğretim Araştırmaları Dergisi - Journal of Research in Education and Teaching, 5(Özel Sayı), 258-265.

Schön, D. (1983). The reflective practitioner. In: New York: Basic Books.

Senemoglu, N. (2010). Gelişim, öğrenme ve öğretim: Kuramdan uygulamaya (development, learning and instruction: from theory to application): Ankara: A Pegem Akademi.

Sizemore, J., \& Zhu, J. (2011). Interactive non-fiction: Towards a new approach for storytelling in digital journalism. Paper presented at the 4th International Conference on Interactive Digital Storytelling (ICIDS 2011), Vancouver, Canada. 
Smeda, N., Dakich, E., \& Sharda, N. (2014). The effectiveness of digital storytelling in the classrooms: a comprehensive study. Smart Learning Environments, $1(1), 6$.

Strampel, K., \& Oliver, R. (2007). Using technology to foster reflection in higher education. Paper presented at the ICT: Providing choices for learners and learning. Proceedings ascilite Singapore 2007.

Sylvester, R., \& Greenidge, W. I. (2009). Digital storytelling: Extending the potential for struggling writers. The reading teacher, 63(4), 284-295.

Şeker-Sezginsoy, B. (2016). An Evaluation of Digital Stories Created for Social Studies Teaching. Journal of Education and Practice, 7(29), 18-29.

Tok, Ş. (2008). Yansıtıcı düşünmeyi geliştirici etkinliklerin öğretmen adaylarının öğretmenlik mesleğine yönelik tutumlarına, performanslarına ve yansıtmalarına etkisi. Egitim ve Bilim, 33(149), 104-117.

TTKB. (2010). Sosyal Bilgiler Dersi 6 ve 7. Sınıflar Öğretim Programı ve Klavuzu. Retrieved from http://ttkb.meb.gov.tr/program2.aspx/program2.aspx?islem=1\&kno=39

Ünver, G. (2003). Yansıtıcı düşünme. Ankara: PegemA Yayıncılık.

Wilson, J., \& Jan, L. W. (1993). Thinking for Themselves: Developing Strategies for Reflective Learning: ERIC.

Yang, Y.-T. C., \& Wu, W.-C. I. (2012). Digital storytelling for enhancing student academic achievement, critical thinking, and learning motivation: A year-long experimental study. Computers \& Education, 59(2), 339-352.

Yıldırım, C. (2012). Bilimsel süreç becerileri etkinliklerinin ilköğretim 7. sınıf öğrencilerinin yansıtıcı düşünmelerine etkisi. Pamukkale Üniversitesi Fen Bilimleri Enstitüsü, 


\section{SUMMARY}

Dewey (1933) deffined reflective thinking as "active, persistent and careful consideration of any belief or supposed form of knowledge in the light of the grounds that support it, and the further conclusions to which it tends, constitutes reflective thought". Reflective thinking is a strong learning experience process that supports understanding of content and knowledge transfer by examining content units with a critical perspective (Strampel \& Oliver, 2007). However, there is less time and opportunity to reflect what we learn in our day (Prensky, 2001). For example, in the social studies course, it is recommended to use methods that provide opportunities for the student to analyze, critically think, collaborate, act independently and do research (Alkan, 1998). On the other hand, it can be said that the preference of the presentation method in practice is one of the most important obstacles for students to get reflective thinking experience in the social studies course (Şeker-Sezginsoy, 2016), where abstract topics are generally included. Another important obstacle is the lack of time and opportunity for reflection thinking activities in the learning-teaching process due to reasons such as crowded classes (Strampel \& Oliver, 2007). In this context, with the developing/developed technologies, new opportunities can be presented to learners to reflect their own learning (Smeda, Dakich, \& Sharda, 2014). However, integrating these innovative technologies into pedagogy is a necessary element of the learning process (Neo \& Neo, 2010). It can give as an example of such technology integration is digital storytelling (DST) that integrates traditional storytelling with multimedia content (Sizemore \& Zhu, 2011). In this context, in this study, it was aimed to examine the effects of digital storytelling activities integrated with social studies course on the development of participants' reflective thinking skills.

In the study, pre-test post-test control group design was used in the semi-experimental method. Implementation was continued for 11 weeks in two classes at the 7th grade level of a middle school in the 2016-2017 education year. The study group consists of 33 participants in the experimental group and 35 in the control group.

"Reflective Thinking Scale" was prepared by Yildirim (2012) for secondary school students as a data collection tool. The reflective thinking scale has a one-factor structure and consists of 17 items. The distribution of the obtained data was examined and the data obtained from the two individuals constituting extreme values in the pre-test and post-test in the control group were not included in the analysis process. Covariance analysis (ANCOVA) was used to compare the scores obtained from the reflective thinking scales applied as pre-test and post-test.

According to the findings of the study, it was concluded that the digital storytelling activities were effective in improving the reflective thinking skill in the social studies class. Regarding this outcome, Barret (2006) notes that digital storytelling activities have a structure that allows learners' participation in learning centered strategies, reflective learning, project-based learning and technology integration strategy.

Relevant to DST's support for reflective learning, Matthews-DeNatale (2008) states that the digital storytelling process allows a reflective learning to be accomplished through which is very difficult to achieve with classical assignments or events (written or printed). To support this, in this study, the topic headings distributed to the learners under the DST in the experimental group were given as research assignments in the reflective learning context to the learners in the control group and reflective thinking skills of control group students showed a limited development although the participants were allowed to present the products they prepared in relation to these assignments.

It has been determined that there is a significant relationship between the level of student engagement in online learning activities/assignments and the development of reflective thinking skills. Accordingly, it can be said that the number of activities/assignments performed by the participants in the online learning environment is positively affected by the development of reflective thinking skills. However, there is a significant difference in favor of the experimental group among the corrected reflective thinking scale development scores according to the number of activities/assignments in the groups' online learning environment. Accordingly, it was concluded that the activities carried out within the context of digital storytelling had a considerable effect on the development of reflective thinking skills. 